\title{
Tetrabranched Hetero-Conjugated Peptides as Bifunctional Agonists of the NOP and mu Opioid Receptors
}

Salvatore Pacifico" Federica Ferrari ${ }^{\S}$, Joaquim Azevedo Neto§, Chiara Sturaro§, Chiara Ruzza ${ }^{\S}$, Girolamo Calò ${ }^{\S}$, Delia Preti"*, and Remo Guerrini"

\# Department of Chemical and Pharmaceutical Sciences, University of Ferrara, Via Luigi Borsari 46, 44121 Ferrara, Italy. ${ }^{\S}$ Department of Medical Sciences, Section of Pharmacology, University of Ferrara Via Fossato di Mortara 17/19, 44121 Ferrara, Italy.

\section{CONTENTS}

\begin{tabular}{|l|r|}
\hline Detailed synthetic procedures & S2 \\
\hline Procedures for biological experiments & $\mathrm{S} 4$ \\
\hline Figure S1. Stability test for H-PWT1-N/OFQ-dermorphin & $\mathrm{S} 6$ \\
\hline${ }^{1}$ H NMR and ${ }^{13}$ C NMR spectra of $\mathbf{1}$ & $\mathrm{S} 7$ \\
\hline HPLC chromatogram and ESI mass spectrum of $\mathbf{1}$ & $\mathrm{S} 8$ \\
\hline${ }^{1}$ H NMR and ${ }^{13}$ C NMR spectra of $\mathbf{2}$ & $\mathrm{S} 9$ \\
\hline HPLC chromatogram and ESI mass spectrum of $\mathbf{2}$ & $\mathrm{S} 10$ \\
\hline${ }^{1}$ H NMR and ${ }^{13}$ C NMR spectra of $\mathbf{3}$ & $\mathrm{S} 11$ \\
\hline HPLC chromatogram and ESI mass spectrum of $\mathbf{3}$ & $\mathrm{S} 12$ \\
\hline HPLC chromatogram and ESI mass spectrum of $\mathbf{6 a}$ & $\mathrm{S} 13$ \\
\hline HPLC chromatogram and ESI mass spectrum of $\mathbf{6 b}$ & $\mathrm{S} 14$ \\
\hline HPLC chromatogram and ESI mass spectrum of $\mathbf{6 c}$ & $\mathrm{S} 15$ \\
\hline HPLC chromatogram and ESI mass spectrum of 7a & $\mathrm{S} 16$ \\
\hline HPLC chromatogram and ESI mass spectrum of 7b & $\mathrm{S} 17$ \\
\hline HPLC chromatogram and ESI mass spectrum of 7c & $\mathrm{S} 18$ \\
\hline HPLC chromatogram and ESI mass spectrum of PWT1-N/OFQ & $\mathrm{S} 19$ \\
\hline HPLC chromatogram and ESI mass spectrum of PWT1-dermorphin & $\mathrm{S} 20$ \\
\hline HPLC chromatogram and ESI mass spectrum of PWT1-dermorphin(O2Oc) $\mathbf{2}$ & $\mathrm{S} 21$ \\
\hline HPLC chromatogram and ESI mass spectrum of PWT1-[Dmt $\left.{ }^{1}\right] \mathbf{d e r m o r p h i n}$ & $\mathrm{S} 22$ \\
\hline
\end{tabular}




\section{CHEMISTRY}

\section{MATERIALS \& METHODS}

Standard Fmoc-protected amino acids, the resin for peptide synthesis and coupling reagents were purchased from Bachem and Sigma-Aldrich. All other commercially available reagents were obtained from Sigma Chemical Co. or E. Merck. Peptides were synthesized on $0.11 \mathrm{mmol}$ scale using a 4(2',4'-dimethoxyphenyl-Fmoc-aminomethyl)-phenoxyacetamido-norleucyl-MBHA resin (Rink amide MBHA resin) on a Syro II peptide synthesizer. Couplings were performed using 1,3diisopropylcarbodiimide (4 equivalents) and 1-hydroxybenzotriazole (4 equivalents) as coupling reagents for 1 hour at room temperature. Fmoc-deprotection was executed in 20\% piperidine in DMF whereas Dde was removed using a $20 \%$ solution of hydrazine in DMF [1]. Peptides were cleaved from the resin using a cleavage cocktail containing 95\% TFA, $2.5 \% \mathrm{H}_{2} \mathrm{O}, 2.5 \%$ triethylsylane at room temperature for 3 hours. Peptides were precipitated from solution with ice cold $\mathrm{Et}_{2} \mathrm{O}$ and centrifuged. Peptides were purified on a reverse-phase Waters Prep 600 HPLC system equipped with a Jupiter column C18 (250 x $30 \mathrm{~mm}, 300 \AA, 15 \mu \mathrm{m}$ spherical particle size $)$. Gradients were run using solvents consisting of $\mathrm{A}\left(\mathrm{H}_{2} \mathrm{O}+0.1 \%\right.$ TFA $)$ and $\mathrm{B}\left(40 \% \mathrm{H}_{2} \mathrm{O}\right.$ in $\mathrm{CH}_{3} \mathrm{CN}+0.1 \%$ TFA $)$ at a flow rate of 20 $\mathrm{ml} / \mathrm{min}$. Analytical determinations of the intermediates and pure compounds were evaluated on a reverse-phase HPLC using a Beckman 126 liquid chromatograph equipped with a Beckman $168 \mathrm{UV}$ vis detector (monitoring at 220 and $254 \mathrm{~nm}$ ). RP-HPLC analytical gradients were run using a solvent system consisting of $\mathrm{A}\left(\mathrm{H}_{2} \mathrm{O}+0.1 \%\right.$ TFA) and $\mathrm{B}\left(\mathrm{CH}_{3} \mathrm{CN}+0.1 \%\right.$ TFA $)$. The conditions used to characterise pure peptides consisted of a linear gradient from $0 \%$ to $100 \%$ solution $\mathrm{B}$ over 25 min on a XBridge ${ }^{\circledR} \mathrm{C} 18$ column $(4.6 \times 150 \mathrm{~mm}, 5 \mu \mathrm{m}$ particle size $)$ at a flow rate of $0.7 \mathrm{ml} / \mathrm{min}$. Analytical RP-HPLC data were reported as column retention time $\left(t_{R}\right)$ in minutes and all products showed a degree of purity $>95 \%$ at 220 and $254 \mathrm{~nm}$. ESI-MS analyses were performed using a ESI Micromass ZMD-2000 (HPLC chromatograms and ESI mass spectra have been reported in the supporting material). NMR spectroscopy was performed using a Varian $400 \mathrm{MHz}$ instrument (s: singolet, d: doublet, dd: double doublet, t: triplet, m: multiplet), all experiments were performed in DMSO- $d_{6}$.

\section{Synthesis of the fully orthogonally protected PWT1 derivative 1.}

To a solution of Z-Lys(Boc)-OH (1 mmol) in DMF, N-methylmorpholine 30\% V/V (5 mmol) and Isobutylchloroformate $(2.2 \mathrm{mmol})$ were added at $0{ }^{\circ} \mathrm{C}$. After 5 minutes, L-Lysinamide, previously dissolved in DMF, was added dropwise. The reaction was warmed to room temperature and left stirring for 4 hours. After this time, the solvent was removed under vacuum then, water was added to the crude residue obtaining a precipitate that was recrystallized from EtOH (white solid, yield 56\%).

${ }^{1} \mathrm{H}$ NMR (DMSO- $\left.d_{6}, 400 \mathrm{MHz}\right): \delta$ 7.86-7.79 (m, 2H), 7.51-7.41 (m, 2H), 7.38-7.29 (m, 11H), 7.02 (bs, 1H), 6.80-6.77 (m, 2H), 5.04-4.97 (m, 4H), 4.19-4.13 (m, 1H), 3.98-3.85 (m, 2H), 3.03-2.95 (m, $2 \mathrm{H}), 2.87-2.84(\mathrm{~m}, 4 \mathrm{H}), 1.62-1.46(\mathrm{~m}, 5 \mathrm{H}), 1.40-1.20(\mathrm{~m}, 31 \mathrm{H}) .{ }^{13} \mathrm{C}$ NMR $\left(\mathrm{DMSO}-d_{6}\right): \delta 174.01$, 173.44, 171.64, 155.96, 155.67, 136.94, 128.27, 127.66, 127.00, 77.28, 65.28, 54.68, 53.85, 52.00, 41.51, 40.29, 31.67, 31.42, 29.78, 29.00, 28.45, 22.66. MS (ESI): $\mathrm{m} / \mathrm{z}$ calcd for $\mathrm{C}_{44} \mathrm{H}_{67} \mathrm{~N}_{7} \mathrm{O}_{11}[\mathrm{M}+\mathrm{H}]^{+}$ 871.05 , found $870.97 . \mathrm{t}_{\mathrm{R}}=19.63$

\section{Synthesis of the bis-maleimide PWT1 derivative 2.}

$\mathrm{Pd} / \mathrm{C}(10 \% \mathrm{mmol})$ was added to a suspension of $1(1 \mathrm{mmol})$ in $\mathrm{MeOH}$ and the reaction was stirred overnight under $\mathrm{H}_{2}$ atmosphere. The mixture was filtered using a celite pad and the filtrate was concentrated under vacuum to obtain an amorphous solid that was suspended in $\mathrm{Et}_{2} \mathrm{O}$ and filtered. This was used in the next step without further purification. The solid was added to a solution of 4maleimidobutyric acid $(1.8 \mathrm{mmol})$, HATU $(1.8 \mathrm{mmol})$ and DIPEA $(2.1 \mathrm{mmol})$ in DMF and the reaction was stirred for 3 hours at room temperature. After the removal of the solvent under vacuum, the desired derivative $\mathbf{2}$ was obtained via crystallization from EtOAc (white solid, yield 50\%).

${ }^{1} \mathrm{H}$ NMR (DMSO- $\left.d_{6}, 400 \mathrm{MHz}\right): \delta$ 7.98-7.96 (m, 1H), 7.89-7.82 (m, 2H), 7.77-7.75 (m, 1H), 7.23 (bs, $1 \mathrm{H}), 7.03-6.96(\mathrm{~m}, 5 \mathrm{H}), 6.76-6.72(\mathrm{~m}, 2 \mathrm{H}), 4.16-4.07(\mathrm{~m}, 3 \mathrm{H}), 3.03-2.94(\mathrm{~m}, 2 \mathrm{H}), 2.90-2.81(\mathrm{~m}$, $6 \mathrm{H}), 2.12-2.08(\mathrm{~m}, 6 \mathrm{H}), 1.71-1.18(\mathrm{~m}, 40 \mathrm{H}) .{ }^{13} \mathrm{C}$ NMR (DMSO- $\left.d_{6}\right): \delta 173.47,171.56,171.40,171.15$, 
171.04, 155.47, 134.40, 77.25, 52.73, 52.41, 52.12, 39.68, 38.32, 36.73, 32.34, 31.88, 31.45, 29.21, 28.69, 28.20, 24.18, 22.72. MS (ESI): $\mathrm{m} / \mathrm{z}$ calcd for $\mathrm{C}_{44} \mathrm{H}_{69} \mathrm{~N}_{9} \mathrm{O}_{13}[\mathrm{M}+\mathrm{H}]^{+}$933.08, found 933.05. $\mathrm{t}_{\mathrm{R}}=$ 17.97

Synthesis of the orthogonally functionalised H-PWT1 core 3.

The intermediate $2(1 \mathrm{mmol})$ was dissolved in TFA $(5 \mathrm{ml})$ and the mixture was stirred at room temperature for 2 hours. After removal of all the volatiles under vacuum, the residue was dissolved in a mixture of DMF $(5 \mathrm{~mL})$ and DIPEA $(3 \mathrm{mmol})$. The resulting solution was added to a stirring mixture of HATU (2.6 mmol), 4-carboxybenzhaldeyde $(2.6 \mathrm{mmol})$ and DIPEA $(2.6 \mathrm{mmol})$ in DMF $(5 \mathrm{~mL})$. The brownish mixture was left stirring overnight at room temperature. After this time, the solvent was removed under vacuum and compound $\mathbf{3}$ was crystallized from acetone/ $\mathrm{Et}_{2} \mathrm{O}$ (white solid, yield $58 \%$ ). The isolated product was used without further purification in the conjugation reaction.

${ }^{1} \mathrm{H}$ NMR (DMSO- $\left.d_{6}, 400 \mathrm{MHz}\right): \delta 10.05$ (s, 2H), 8.63-8.59 (m, 2H), 7.97-7.92 (m, 14H), 7.01-6.91 $(\mathrm{m}, 4 \mathrm{H}), 4.20-4.04(\mathrm{~m}, 3 \mathrm{H}), 3.62-2.86(\mathrm{~m}, 8 \mathrm{H}$ with residual water of the deuterated solvent), 2.12$2.05(\mathrm{~m}, 6 \mathrm{H}), 1.74-1.15(\mathrm{~m}, 22 \mathrm{H}) .{ }^{13} \mathrm{C}$ NMR (DMSO- $\left.d_{6}\right): \delta 192.79,173.42,171.51,171.34,171.11$, $170.93,165.14,139.58,137.52,134.32,129.24,127.75,53.18,52.63,52.21,41.51,38.27,36.66$, 32.24, 31.80, 31.36, 28.61, 24.05, 22.80. MS (ESI): $\mathrm{m} / \mathrm{z}$ calcd for $\mathrm{C}_{50} \mathrm{H}_{61} \mathrm{~N}_{9} \mathrm{O}_{13}[\mathrm{M}+\mathrm{H}]^{+} 997.08$, found 996.75. $\mathrm{t}_{\mathrm{R}}=17.73$

\section{Synthesis of the hydrazinobenzoic dermorphin derivatives 6a-c.}

The resin supported peptide derivatives 4a-c were swelled in DMF for 5 minutes, then a 20\% v/v hydrazine solution in DMF was added $(3 \times 2 \mathrm{~mL})$ and the reaction proceeded for 30 minutes. The resin was washed with DMF, $\mathrm{MeOH}$ and finally DCM. A solution of Boc-hydrazinobenzoic acid (1.1 eq), HATU (1.1 eq) and DIPEA (1.1 eq) in DMF (2 mL) was added to the previously swelled resin. This suspension was stirred for 3.5 hours and after this time the resin was washed with DMF, $\mathrm{MeOH}$ and DCM. The resin was treated with the cleavage cocktail for 2 hours. The suspension was filtered and the liquid phase was concentrated to give an amorphous pale yellow solid after precipitation from ether. Compounds 6a-c were finally purified by preparative HPLC (pale yellow solids, yield 58-64 $\%)$.

MS (ESI) 6a: $\mathrm{m} / \mathrm{z}$ calcd for $\mathrm{C}_{53} \mathrm{H}_{68} \mathrm{~N}_{12} \mathrm{O}_{12}[\mathrm{M}+\mathrm{H}]^{+} 1066.19$, found 1066.09. $\mathrm{t}_{\mathrm{R}}=16.00$

MS (ESI) 6b: $\mathrm{m} / \mathrm{z}$ calcd for $\mathrm{C}_{65} \mathrm{H}_{90} \mathrm{~N}_{14} \mathrm{O}_{18}[\mathrm{M}+\mathrm{H}]^{+} 1356.50$, found 1356.40. $\mathrm{t}_{\mathrm{R}}=12.52$

MS (ESI) 6c: $\mathrm{m} / \mathrm{z}$ calcd for $\mathrm{C}_{55} \mathrm{H}_{72} \mathrm{~N}_{12} \mathrm{O}_{12}[\mathrm{M}+\mathrm{H}]^{+} 1094.24$, found 1093.86. $\mathrm{t}_{\mathrm{R}}=12.89$

\section{General procedure for the synthesis of the H-PWT1 derivatives 7a-7c.}

To a solution of $3(1 \mu \mathrm{mol})$ and $\left[\mathrm{Cys}^{18}\right] \mathrm{N} / \mathrm{OFQ}-\mathrm{NH}_{2}(2.1 \mathrm{eq})$ in dried DMF $(300 \mu \mathrm{l}), 10 \mu \mathrm{L}$ of a $5 \%$ aqueous solution of $\mathrm{NaHCO}_{3}$ were added. After 5 minutes, the ESI-MS spectrum showed the complete consumption of 3 . Then, the $\mathrm{pH}$ of the solution was adjusted with $\mathrm{CH}_{3} \mathrm{COOH}$ to reach $\mathrm{pH}$ 3 and the hydrazinobenzoic derivatives $6 \mathbf{a}-\mathbf{c}(2.5 \mathrm{eq})$ were added. The reaction was stirred at room temperature for 30 minutes. After this time, the solvent was removed under vacuum and the residue was purified by preparative HPLC to give 7a-c (pale yellow solids, yield 20-39\%).

MS (ESI) 7a: $\mathrm{m} / \mathrm{z}$ calcd for $\mathrm{C}_{320} \mathrm{H}_{463} \mathrm{~N}_{91} \mathrm{O}_{79} \mathrm{~S}_{2}[\mathrm{M}+7 \mathrm{H}]^{7+}$ 988.54, found 988.94. $\mathrm{t}_{\mathrm{R}}=11.57$

MS (ESI) 7b: $\mathrm{m} / \mathrm{z}$ calcd for $\mathrm{C}_{344} \mathrm{H}_{507} \mathrm{~N}_{95} \mathrm{O}_{91} \mathrm{~S}_{2}[\mathrm{M}+8 \mathrm{H}]^{8+}$ 937.62, found 937.70. $\mathrm{t}_{\mathrm{R}}=13.43$

MS (ESI) 7c: $\mathrm{m} / \mathrm{z}$ calcd for $\mathrm{C}_{324} \mathrm{H}_{471} \mathrm{~N}_{91} \mathrm{O}_{79} \mathrm{~S}_{2}[\mathrm{M}+5 \mathrm{H}]^{5+} 1394.78$, found 1394.85. $\mathrm{t}_{\mathrm{R}}=14.82$

Synthesis of the Homotetrameric derivatives PWT1-N/OFQ, PWT1-Dermorphin, PWT1dermorphin(O2Oc) $)_{2}$, PWT1-[Dmt $\left.{ }^{1}\right]$ dermorphin.

To a solution of the tetramaleimide PWT1 core $(1 \mu \mathrm{mol}$, Figure 1$)$ and the proper C-terminal cysteinefunctionalized peptide (4,4 eq) in $\mathrm{CH}_{3} \mathrm{CN} / \mathrm{H}_{2} \mathrm{O}(250 \mu \mathrm{L} / 250 \mu \mathrm{L}), 10 \mu \mathrm{L}$ of a $5 \%$ aqueous solution of $\mathrm{NaHCO}_{3}$ were added. After 5 minutes, the ESI-MS spectrum showed the complete consumption of the starting core. The solution was directly injected in preparative HPLC to give the pure homotetrameric PWT1 derivatives in quantitative yields. 
MS (ESI) PWT1-N/OFQ: $\mathrm{m} / \mathrm{z}$ calcd for $\mathrm{C}_{378} \mathrm{H}_{607} \mathrm{~N}_{127} \mathrm{O}_{103} \mathrm{~S}_{4}[\mathrm{M}+10 \mathrm{H}]^{10+} 871.70$, found 871.65. $\mathrm{t}_{\mathrm{R}}=$ 12.92

MS (ESI) PWT1- Dermorphin: m/z calcd for $\mathrm{C}_{222} \mathrm{H}_{287} \mathrm{~N}_{47} \mathrm{O}_{59} \mathrm{~S}_{4}[\mathrm{M}+4 \mathrm{H}]^{4+} 1172.55$, found 1172.52 . $t_{R}=15.07$

MS (ESI) PWT1-dermorphin(O2Oc) $)_{2}: \mathrm{m} / \mathrm{z}$ calcd for $\mathrm{C}_{270} \mathrm{H}_{375} \mathrm{~N}_{55} \mathrm{O}_{83} \mathrm{~S}_{4}[\mathrm{M}+4 \mathrm{H}]^{4+} 1462.86$, found 1462.92. $\mathrm{t}_{\mathrm{R}}=15.13$

MS (ESI) PWT1-[Dmt ${ }^{1}$ ]dermorphin: $\mathrm{m} / \mathrm{z}$ calcd for $\mathrm{C}_{230} \mathrm{H}_{303} \mathrm{~N}_{47} \mathrm{O}_{59} \mathrm{~S}_{4}[\mathrm{M}+4 \mathrm{H}]^{4+} 1200.60$, found 1200.96. $\mathrm{t}_{\mathrm{R}}=14.88$

\section{PHARMACOLOGY}

\section{MATERIALS \& METHODS}

\section{Calcium mobilization assay}

CHO cells stably coexpressing either the human recombinant NOP or MOP receptor along with the C-terminally modified $\mathrm{G}_{\mathrm{qi}}$ chimeric protein were generated as previously described $[2,3]$. Cells were cultured in culture medium consisting of Dulbecco's modified Eagle's medium (DMEM)/HAMS F12 (1:1) supplemented with 10\% fetal bovine serum (FBS), penicillin (100 IU/ml), streptomycin $(100 \mu \mathrm{g} / \mathrm{ml})$, L-glutamine $(2 \mathrm{mM})$; fungizone $(1 \mu \mathrm{g} / \mathrm{ml})$, geneticin $(\mathrm{G} 418 ; 200 \mu \mathrm{g} / \mathrm{ml})$ and hygromycin B $(100 \mu \mathrm{g} / \mathrm{ml})$. Cell cultures were kept at $37{ }^{\circ} \mathrm{C}$ in $5 \% \mathrm{CO}_{2} /$ humidified air. Cells were seeded at a density of 50,000 cells/well into 96-well black, clear-bottom plates. After $24 \mathrm{~h}$ incubation the cells were loaded with Hank's Balanced Salt Solution (HBSS) supplemented with 2.5 $\mathrm{mM}$ probenecid, $3 \mu \mathrm{M}$ of the calcium sensitive fluorescent dye Fluo-4 AM, 0.01\% pluronic acid and $20 \mathrm{mM}$ HEPES ( $\mathrm{pH} \mathrm{7.4)}$ for $30 \mathrm{~min}$ at $37^{\circ} \mathrm{C}$. Afterwards the loading solution was aspirated and a washing step with $100 \mu \mathrm{l} /$ well of HBSS, HEPES $(20 \mathrm{mM}$, pH 7.4), $2.5 \mathrm{mM}$ probenecid and $500 \mu \mathrm{M}$ Brilliant Black was carried out. Subsequently $100 \mu \mathrm{l} /$ well of the same buffer was added. After placing cell culture and compound plates into the FlexStation II (Molecular Devices, Sunnyvale, CA, USA), fluorescence changes were measured after $10 \mathrm{~min}$ of stabilization at $37^{\circ} \mathrm{C}$. On-line additions were carried out in a volume of $50 \mu \mathrm{l} /$ well.

Dynamic mass redistribution assay - $\mathrm{CHO}$ cells stably expressing the human NOP receptor $\left(\mathrm{CHO}_{\mathrm{NOP}}\right)$ were kindly provided by D.G. Lambert (University of Leicester, UK). $\mathrm{CHO}_{\mathrm{MOP}}$ cells were provided by L Toll (Torrey Pines Institute for Molecular Studies, Port St. Lucie, USA). Cells were cultured in culture medium consisting of Dulbecco's modified Eagle's medium (DMEM)/HAMS F12 (1:1) supplemented with $10 \%$ fetal bovine serum (FBS), penicillin $(100 \mathrm{IU} / \mathrm{ml})$, streptomycin $(100$ $\mu \mathrm{g} / \mathrm{ml})$, L-glutamine $(2 \mathrm{mM})$; fungizone $(1 \mu \mathrm{g} / \mathrm{ml})$, and geneticin $(\mathrm{G} 418 ; 400 \mu \mathrm{g} / \mathrm{ml})$. Confluent cells were sub-cultured using trypsin/EDTA and used for experiments. Cells were seeded at a density of 15,000 cells/well in $30 \mu \mathrm{l}$ into fibronectin-coated EnspireTM-LC 384-wells plates and cultured for 20 hours to form a confluent monolayer. On the day of the experiment, cells were manually washed twice and maintained with assay buffer for 90 minutes before DMR experiments. DMR was monitored in real time with a temporal resolution of $44 \mathrm{sec}$ throughout the assay. Experiments were performed at $37^{\circ} \mathrm{C}$, using an EnSight Multimode Plate Reader (PerkinElmer), that uses the Corning ${ }^{\circledR}$ Epic ${ }^{\circledR}$ Technology to measure the DMR signal. A 5 min baseline was first established, followed by adding compounds manually in a volume of $10 \mu \mathrm{l}$ and recording compounds-triggered DMR signal for $60 \mathrm{~min}$. Maximum picometers ( $\mathrm{pm}$ ) modification (peak) were used to determine agonist response after baseline normalization.

Data analysis and terminology. The pharmacological terminology adopted in this paper is consistent with IUPHAR recommendations [4]. All data are expressed as the mean \pm standard error of the mean (SEM) of $n$ experiments. For potency values $95 \%$ confidence limits were indicated $\left(\mathrm{CL}_{95 \%}\right)$. In calcium mobilization experiments, maximum change in fluorescence, expressed as percent over the 
baseline fluorescence, was used to determine agonist response. In DMR experiments maximum picometers $(\mathrm{pm})$ modification (peak) were used to determine agonist response after baseline normalization. Agonist potencies are given as $\mathrm{pEC}_{50}$ i.e. the negative logarithm to base 10 of the molar concentration of an agonist that produces $50 \%$ of the maximal effect of that agonist. Concentration-response curves to agonists were fitted to the classical four-parameter logistic nonlinear regression model:

Effect $=$ Baseline $+($ Emax - Baseline $) /\left(1+10^{\wedge}\left(\left(\operatorname{LogEC} C_{50}-\log [\right.\right.\right.$ compound $\left.]\right)$ HillSlope $\left.)\right)$

Curves fitting were performed using PRISM 6.0 (GraphPad Software In., San Diego, USA).

\section{References}

(1) Bycroft, B. W., Chan, W. C., Chhabra, S. R., Hone, N. D. (1993) A Novel Lysine-protecting Procedure for Continuous Flow Solid Phase Branched Peptides. J Chem Soc Chem Commun. 9, 778-779.

(2) Camarda, V., Calo, G. (2013) Chimeric G proteins in fluorimetric calcium assays: experience with opioid receptors. Methods Mol Biol. 937, 293-306.

(3) Camarda, V., Fischetti, C., Anzellotti, N., Molinari, P., Ambrosio, C., Kostenis, E., Regoli, D., Trapella, C., Guerrini, R., Severo, S., Calo, G. (2009) Pharmacological profile of NOP receptors coupled with calcium signaling via the chimeric protein $\mathrm{G}$ alpha qi5. Naunyn Schmiedebergs Arch Pharmacol. 379(6), 599-607.

(4) Neubig, R. R., Spedding, M., Kenakin, T., Christopoulos, A., International Union of Pharmacology Committee on Receptor Nomenclature and Drug Classification. (2003) International Union of Pharmacology Committee on Receptor Nomenclature and Drug Classification. XXXVIII. Update on terms and symbols in quantitative pharmacology. Pharmacol Rev. 55(4), 597-606. 


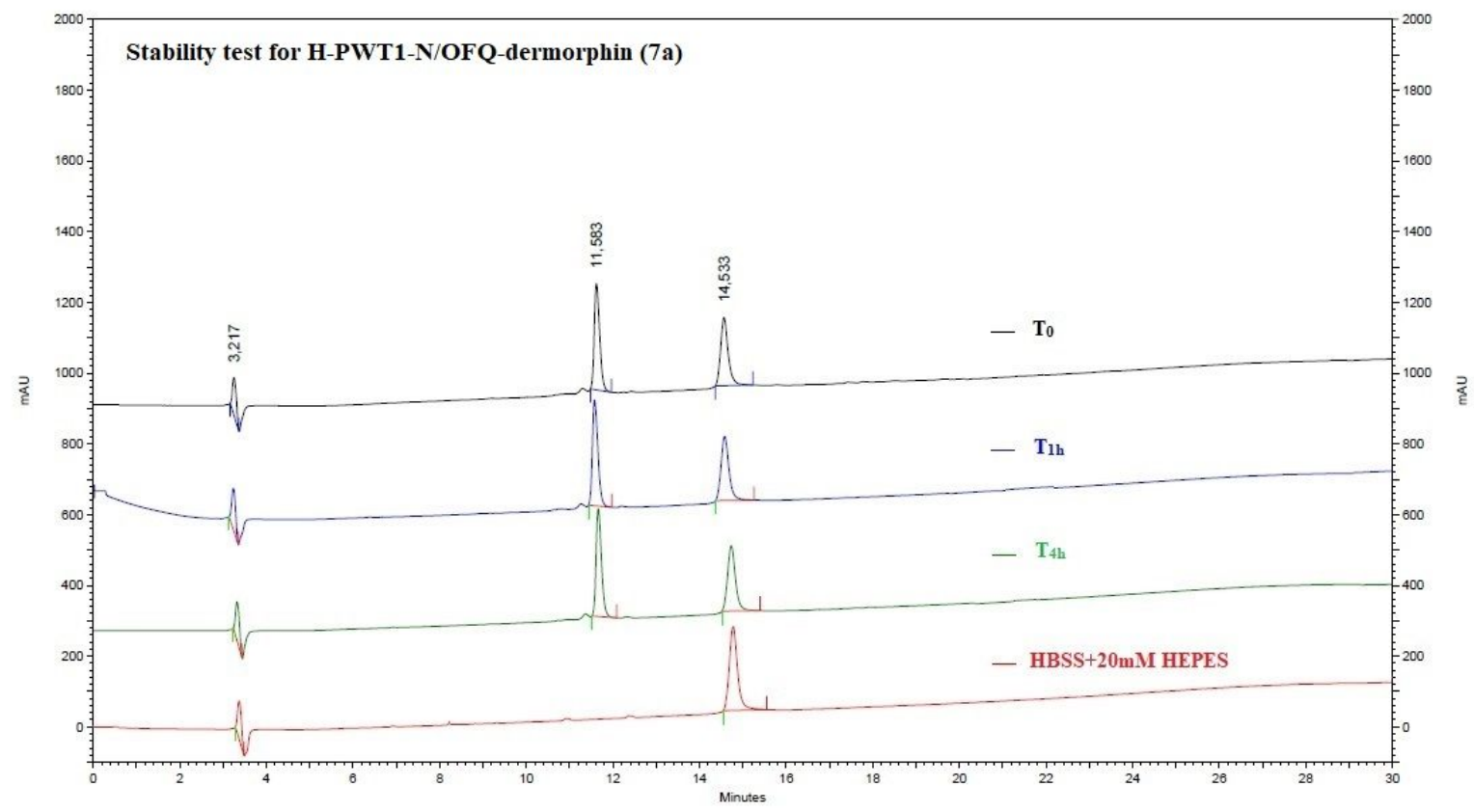

Figure S1. Stability test for H-PWT1-N/OFQ-dermorphin in HBSS supplemented with $20 \mathrm{mM}$ HEPES ( $\mathrm{pH} 7.5$ ). At the bottom is reported the chromatogram of the buffer solution (red line). The upper chromatograms were recorded at time zero $\left(\mathrm{T}_{0}\right)$ and after $1 \mathrm{~h}\left(\mathrm{~T}_{1 \mathrm{~h}}\right)$ and $4 \mathrm{~h}\left(\mathrm{~T}_{4 \mathrm{~h}}\right)$ of incubation. No variations were observed over the monitoring times with the persistence of the two peaks of the buffer $\left(T_{R}=14.533\right)$ and the unaltered compound $7 \mathbf{a}\left(T_{R}=11.583\right.$, see the single injection below $)$. 
PWT1 derivative 1

${ }^{1}$ H NMR

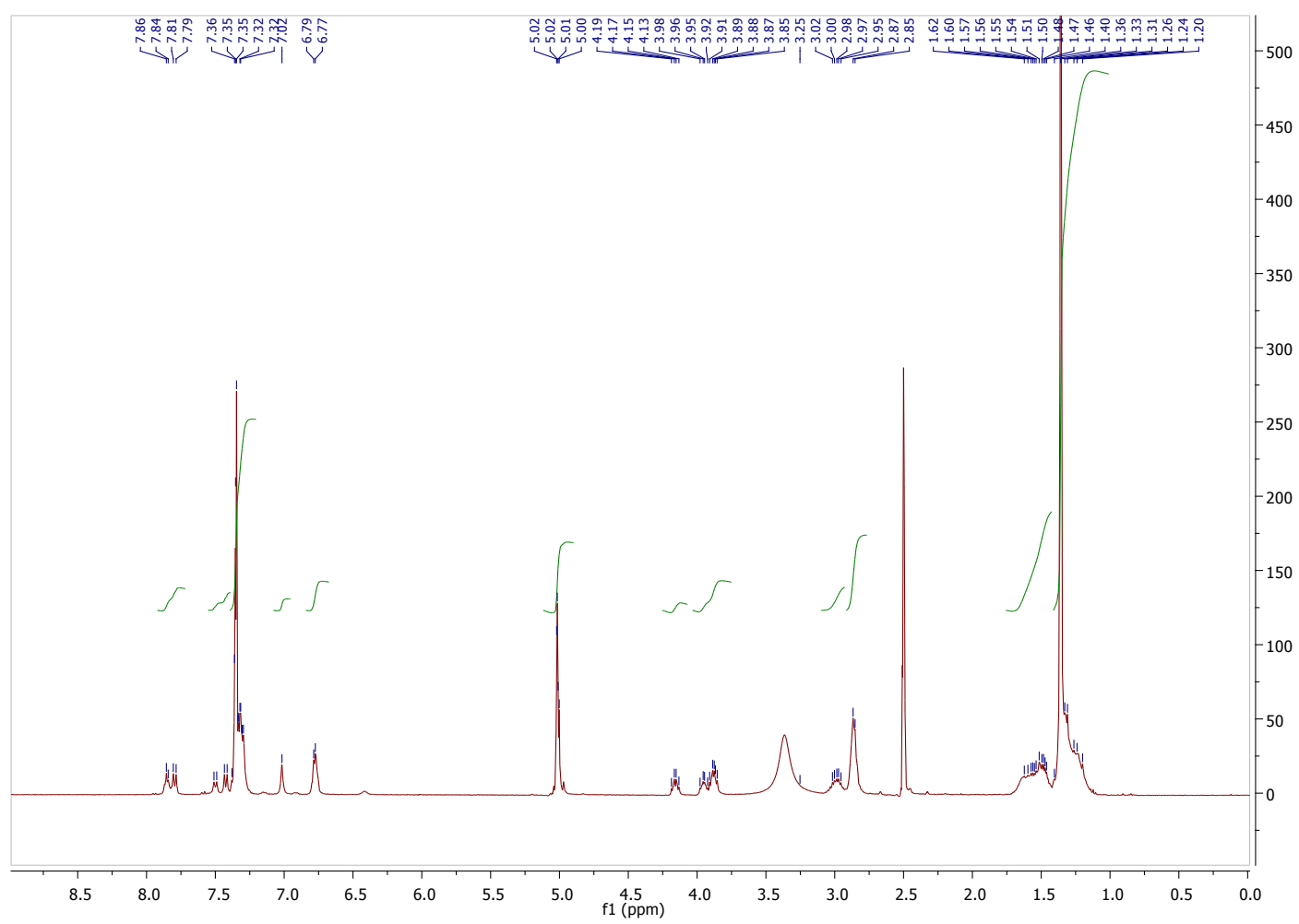

${ }^{13}$ C NMR

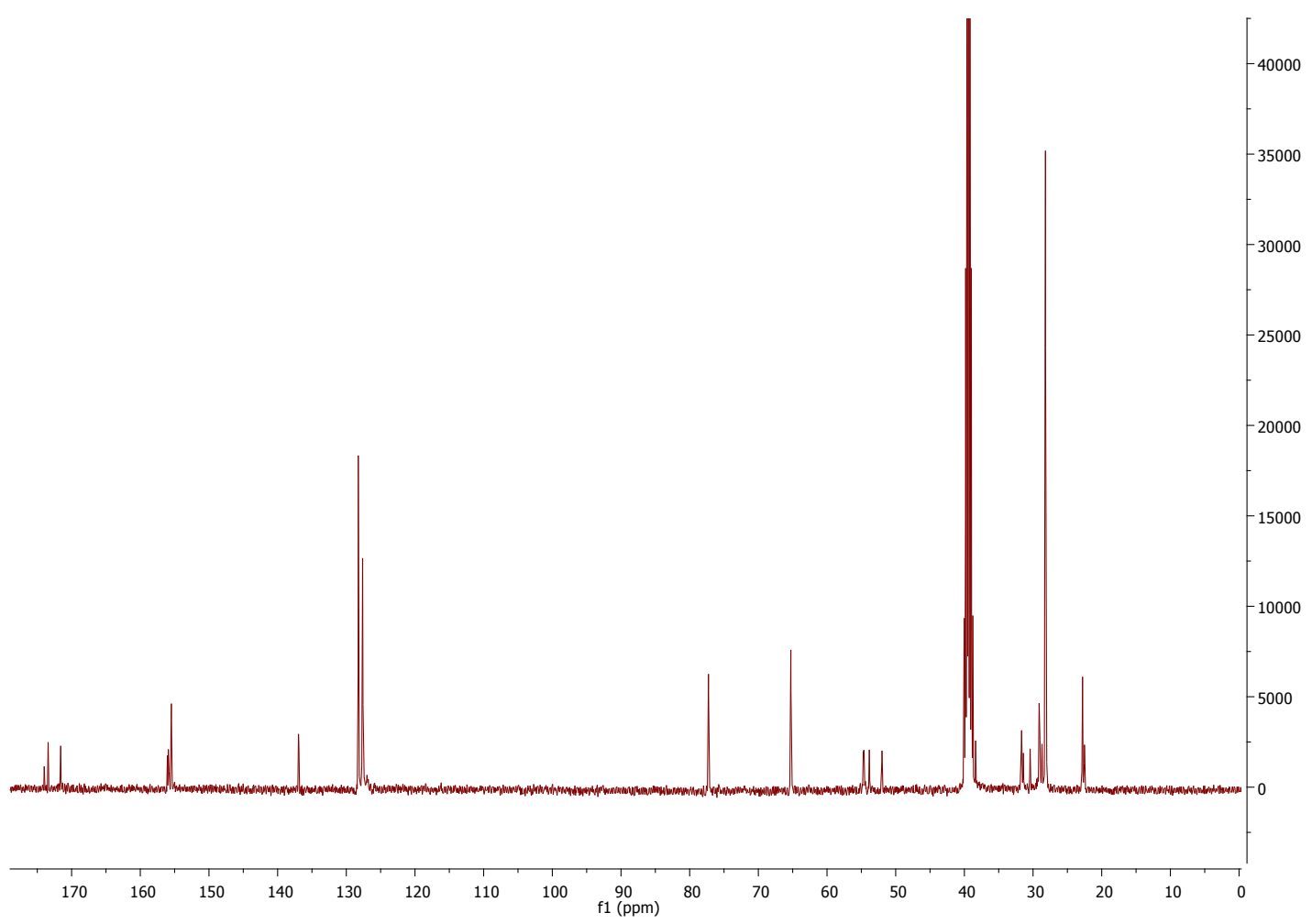


PWT1 derivative 1
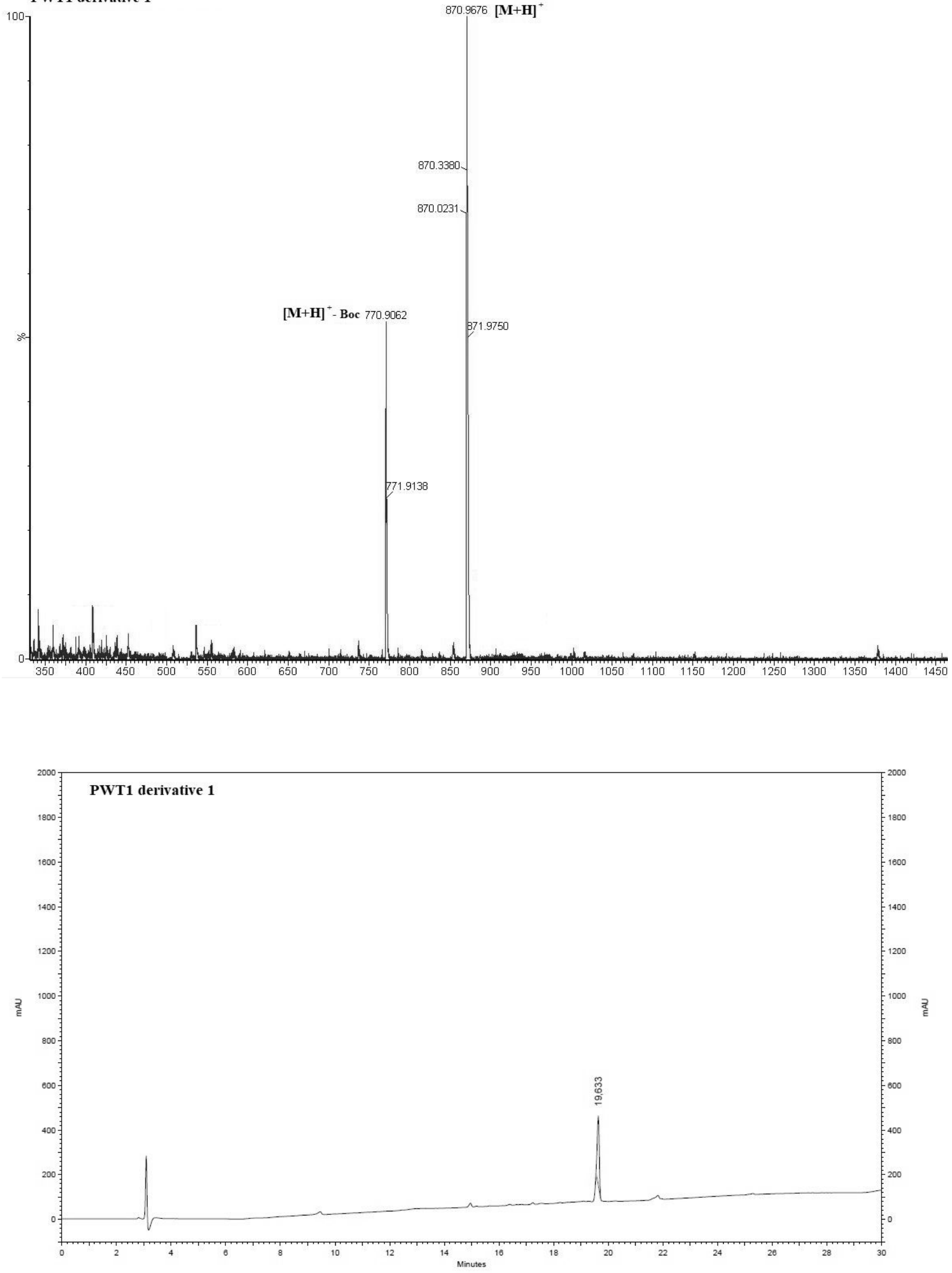
PWT1 derivative 2

${ }^{1}$ H NMR

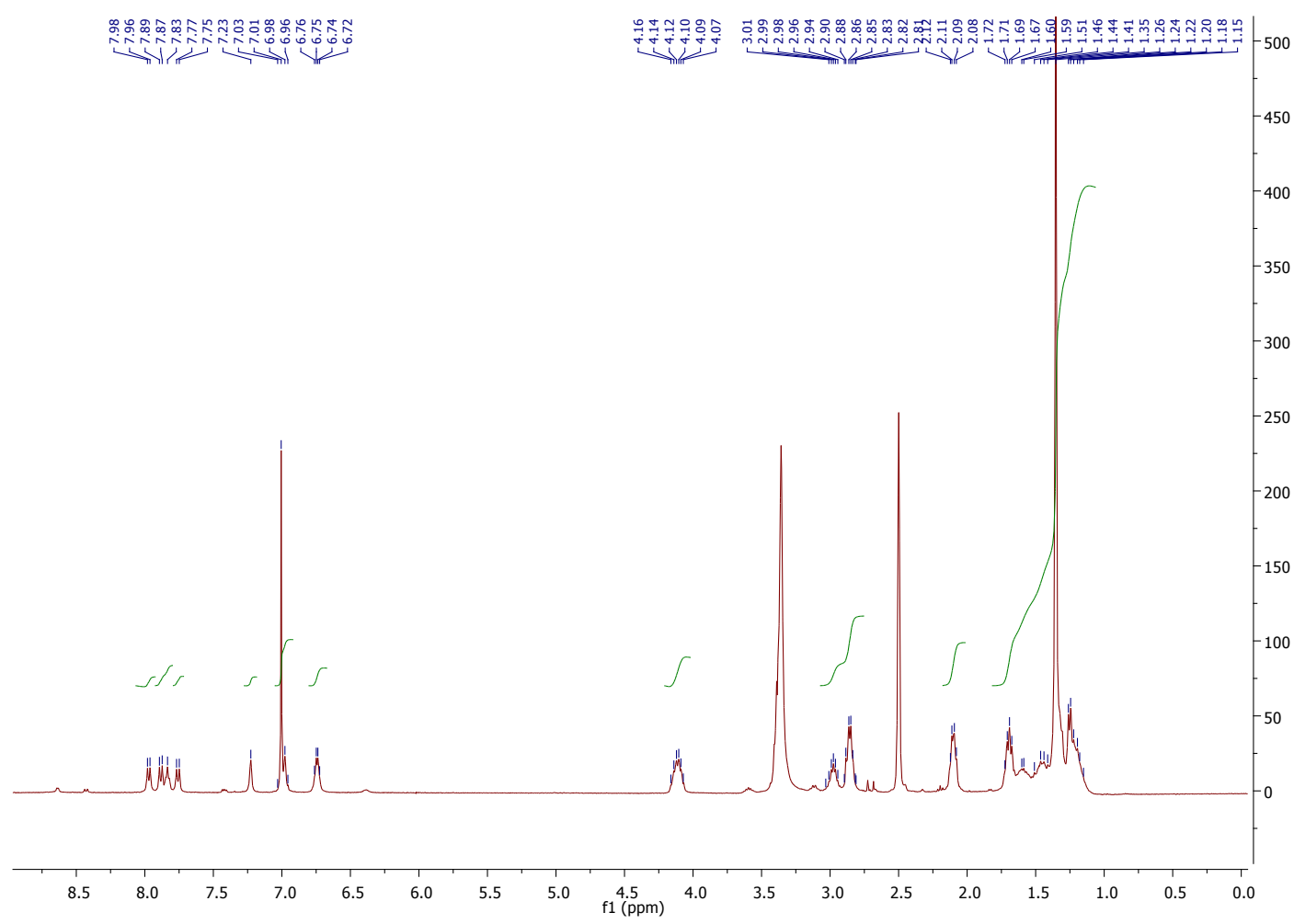

${ }^{13}$ C NMR

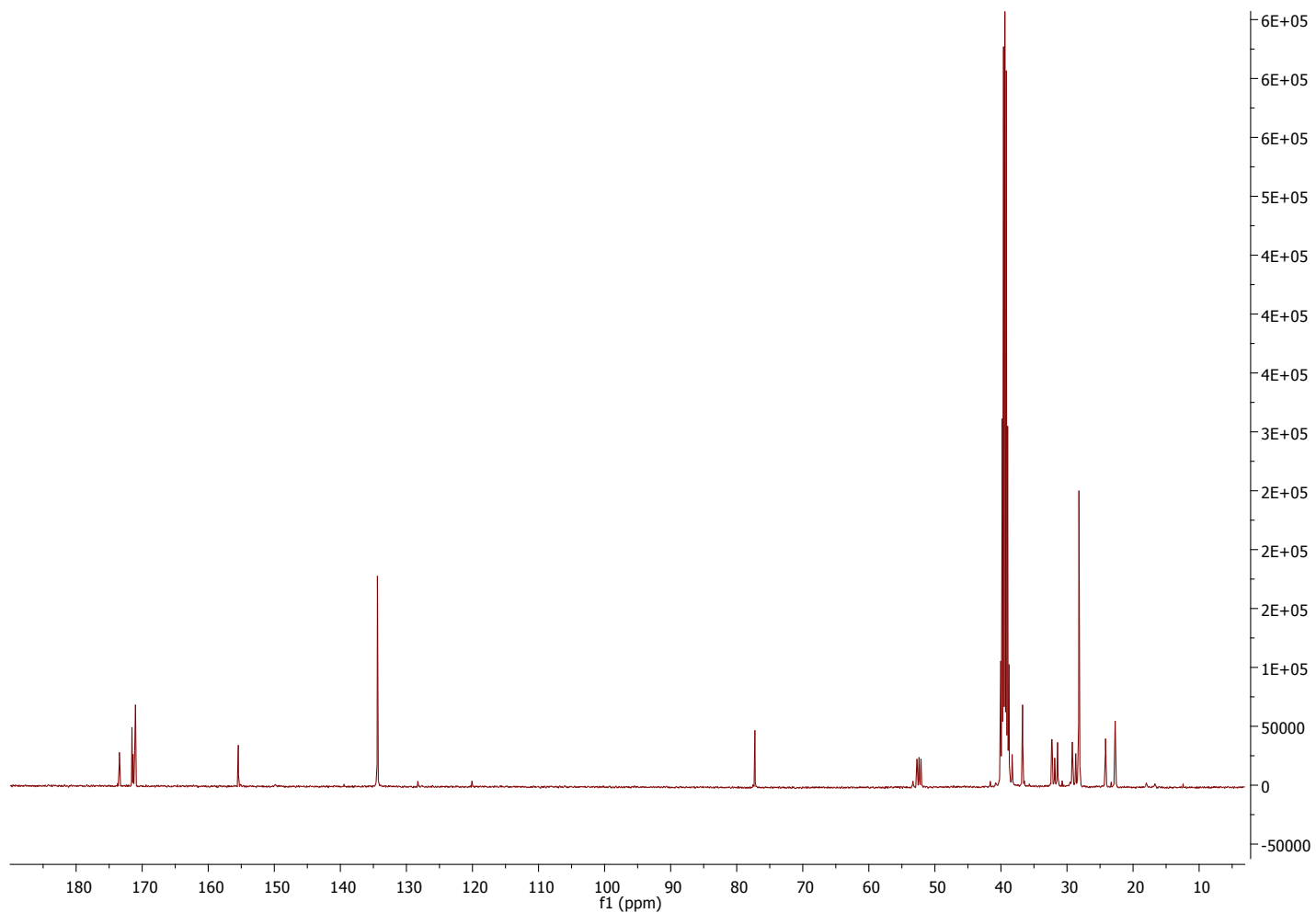



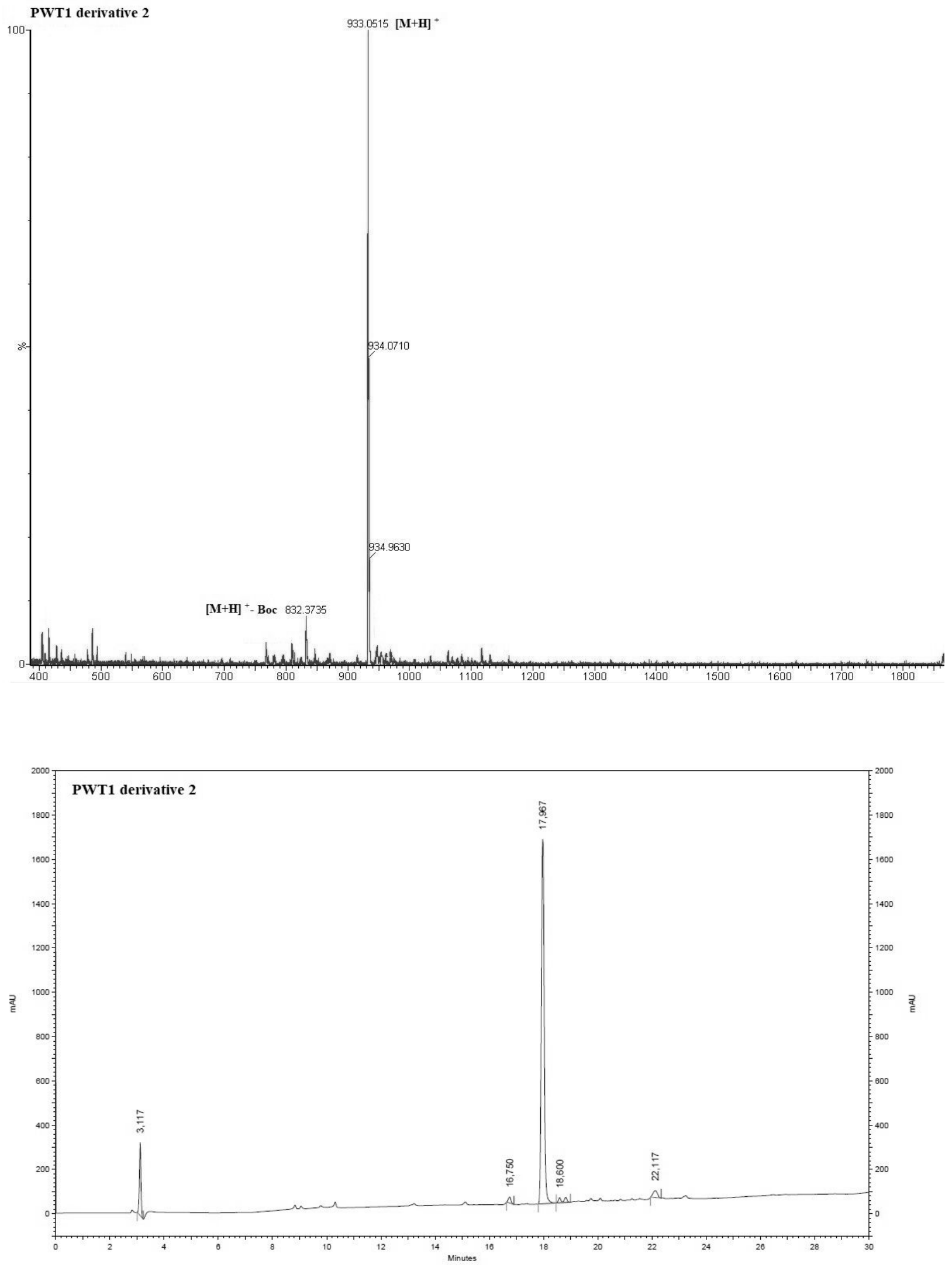


\section{H-PWT1 core 3}

${ }^{1}$ H NMR

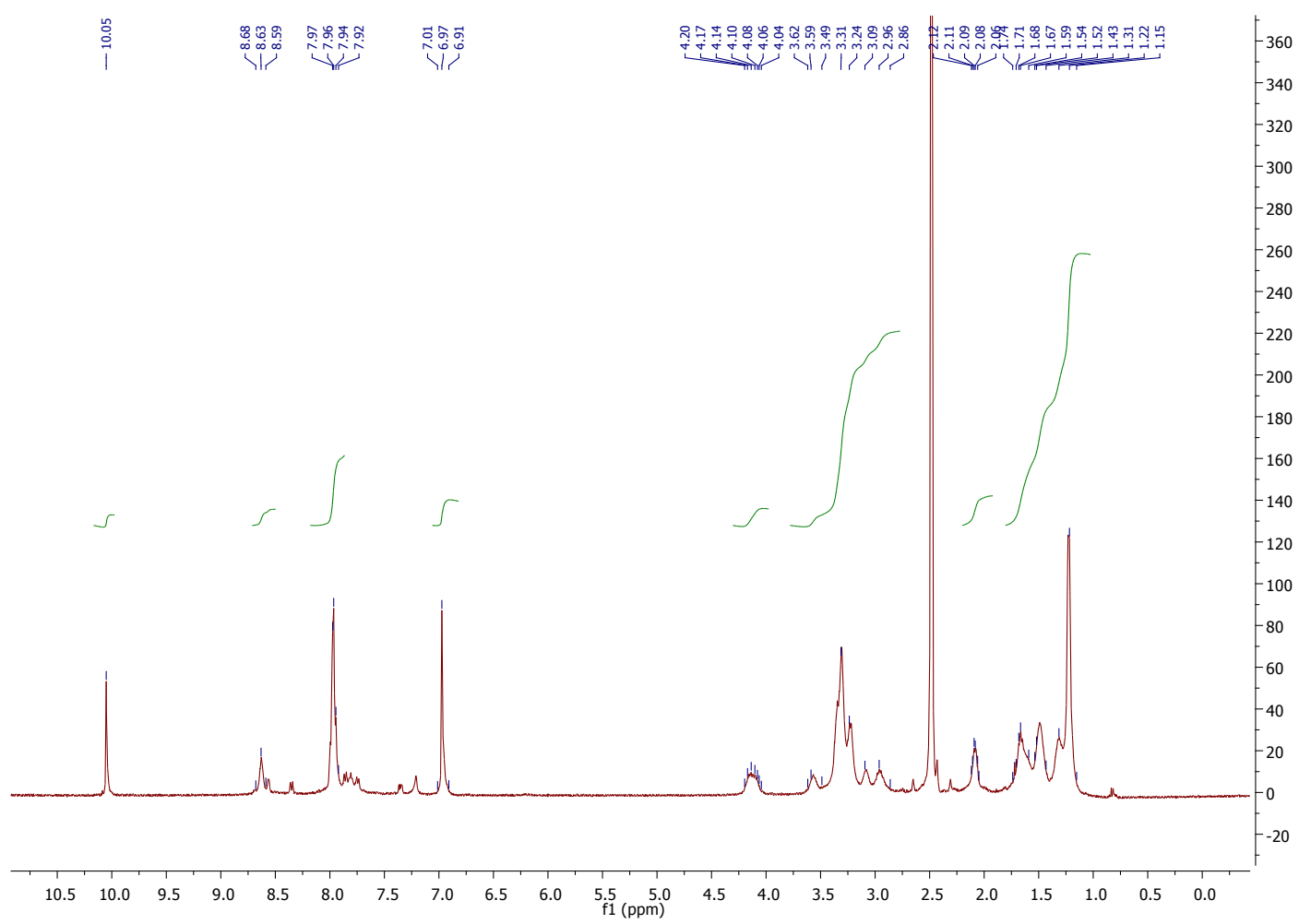

${ }^{13}$ C NMR

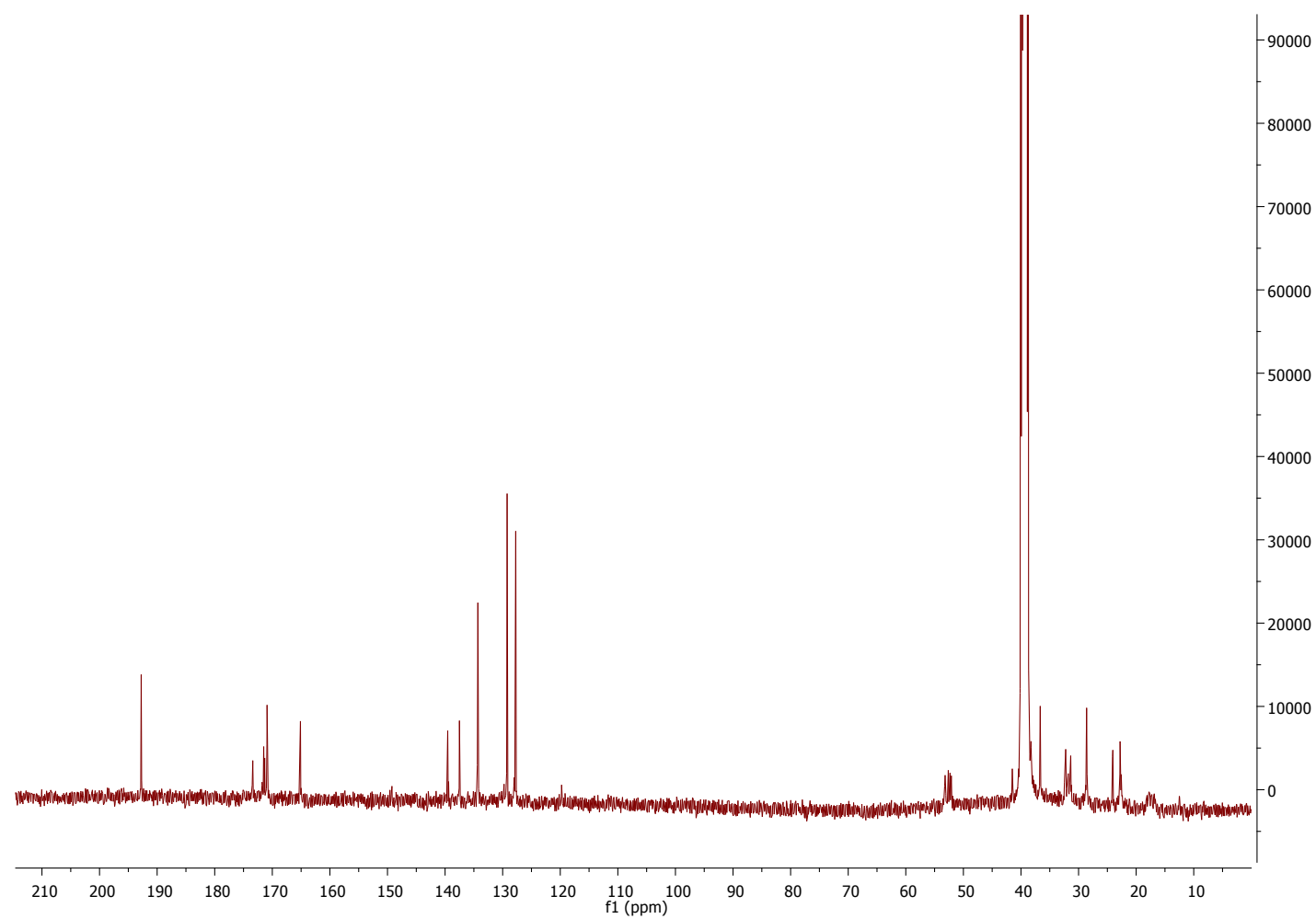


H-PWT1 core 3
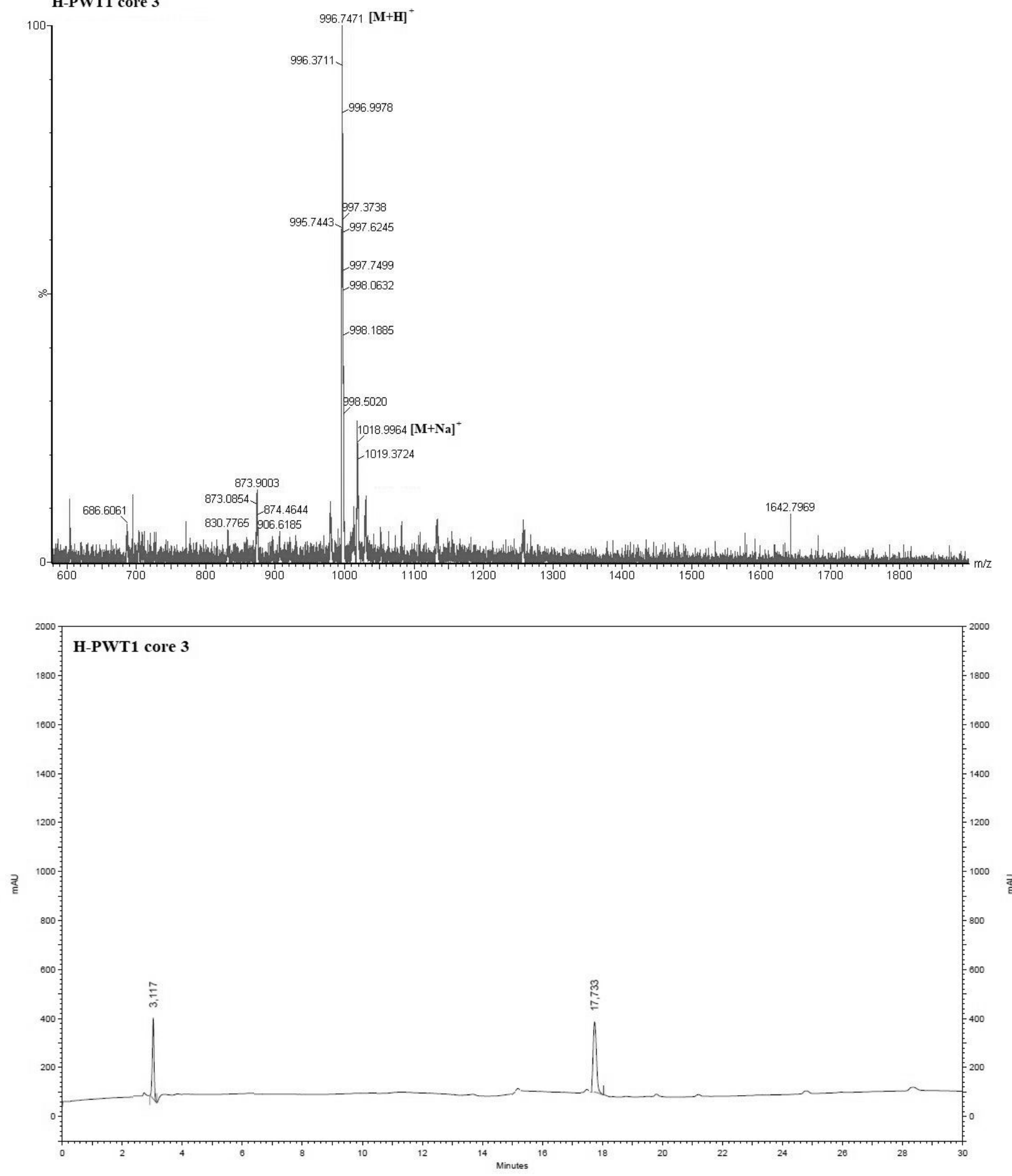


\section{Hydrazinobenzoic dermorphin derivative $6 a$}
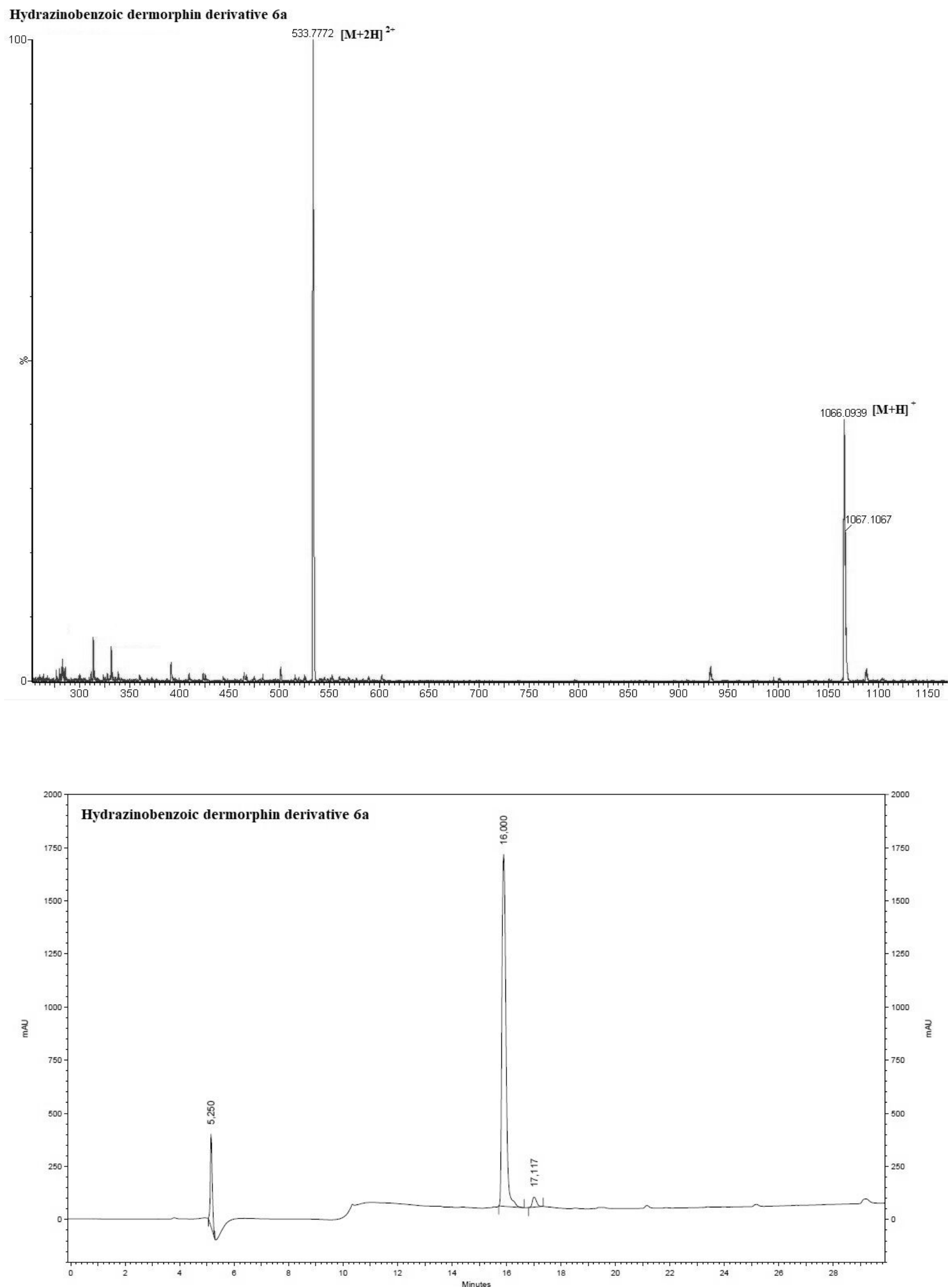
Hydrazinobenzoic dermorphin derivative $6 b$
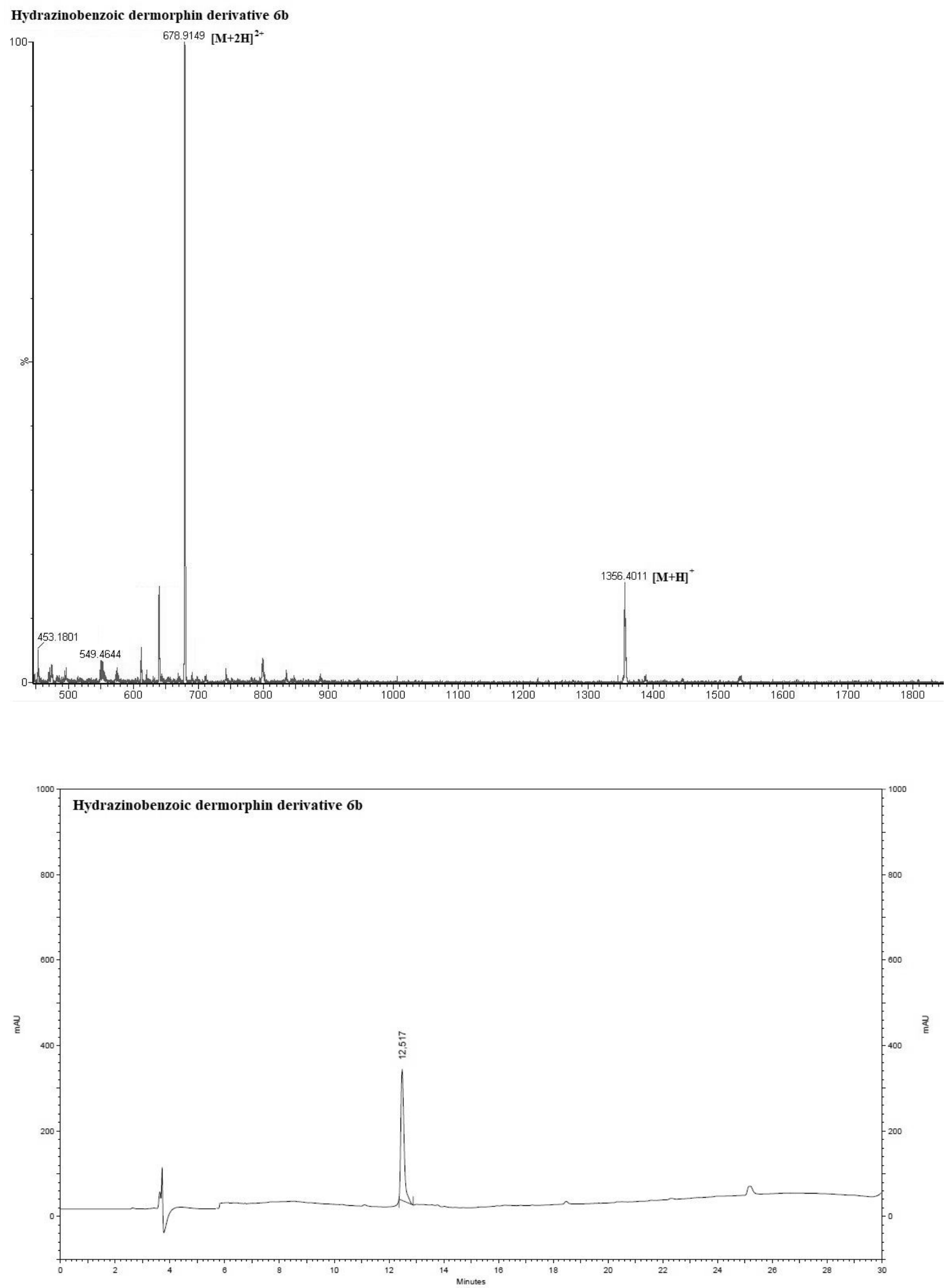
Hydrazinobenzoic dermorphin derivative 6c
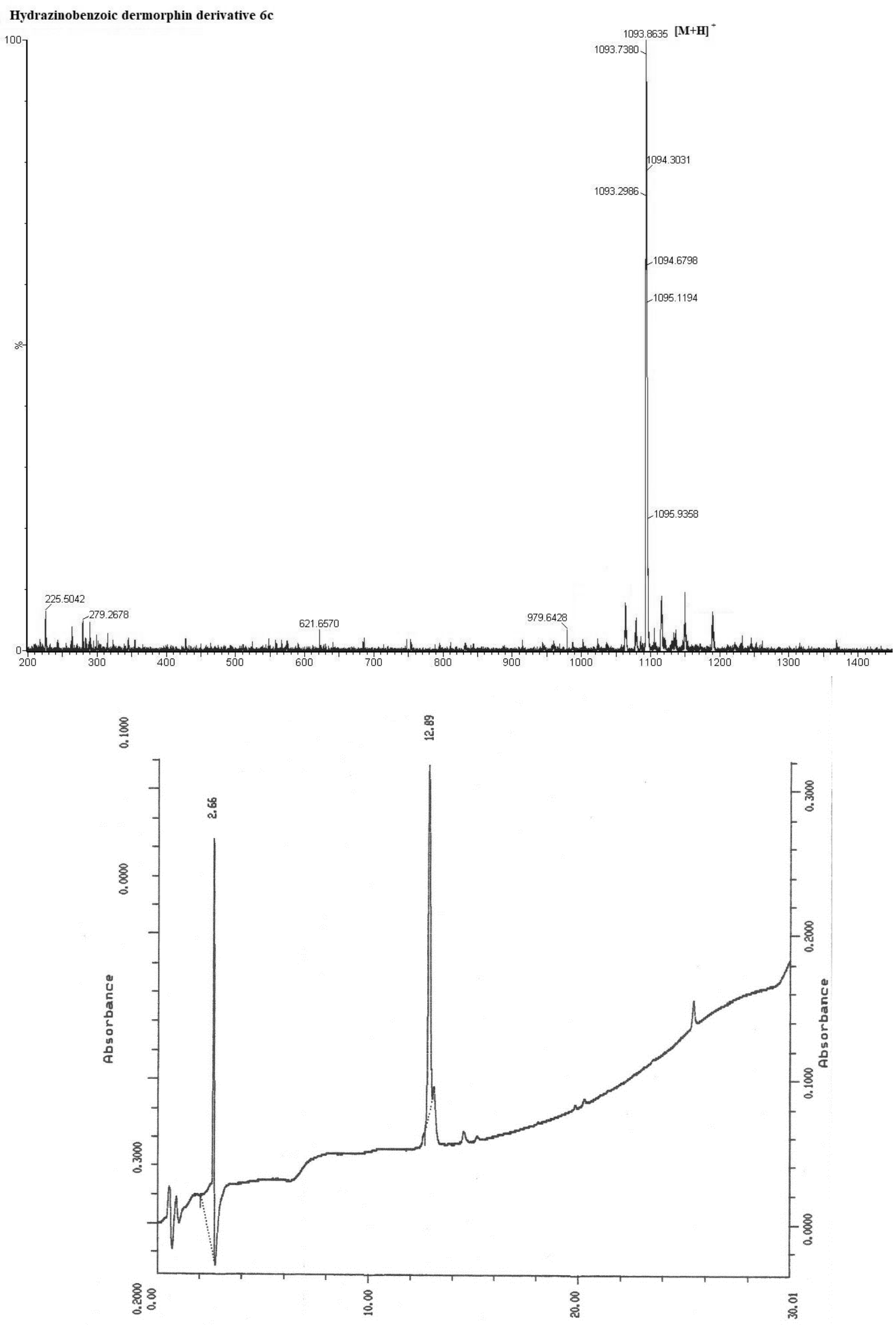


\section{H-PWT1 derivative 7a}
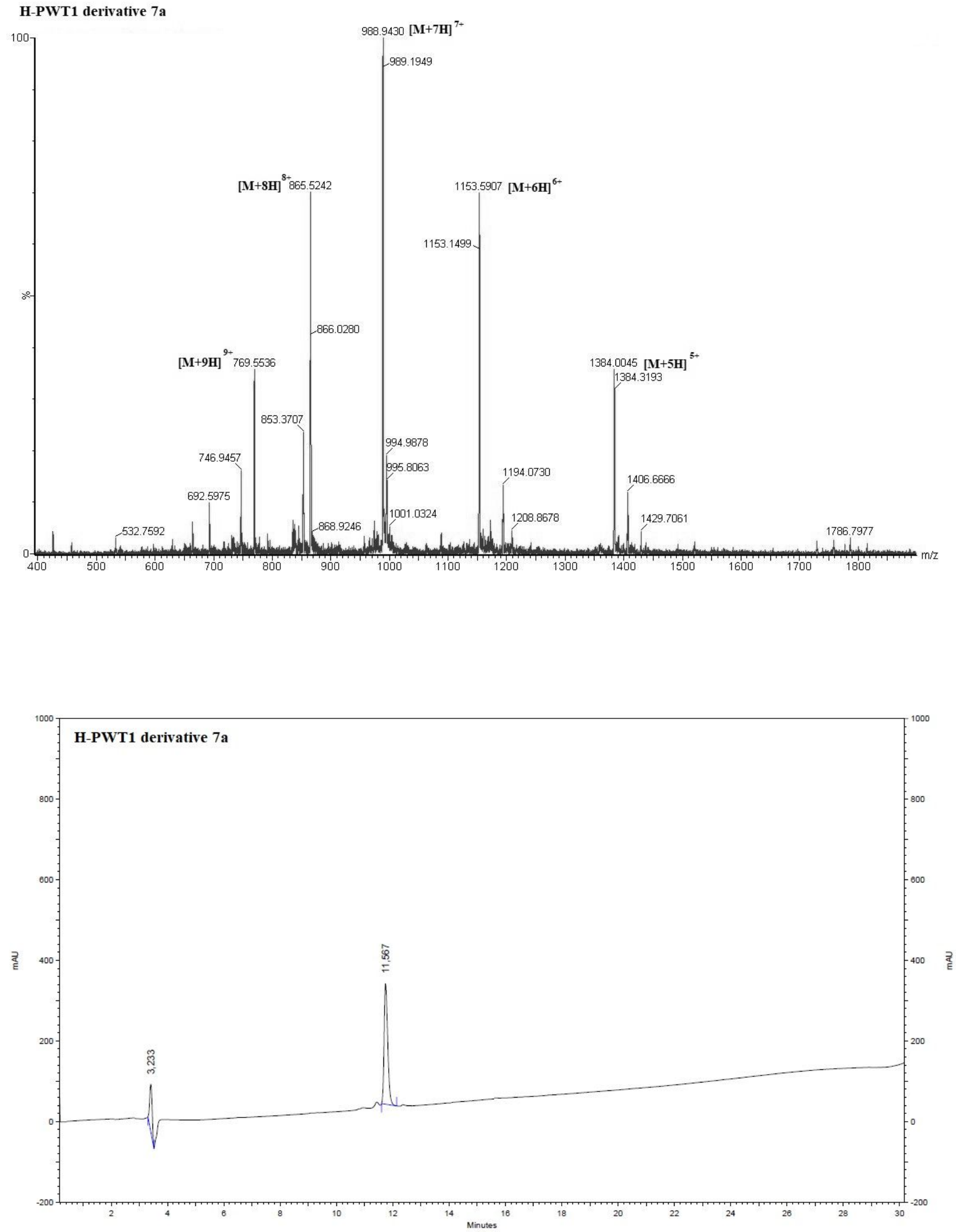


\section{H-PWT1 derivative 7b}
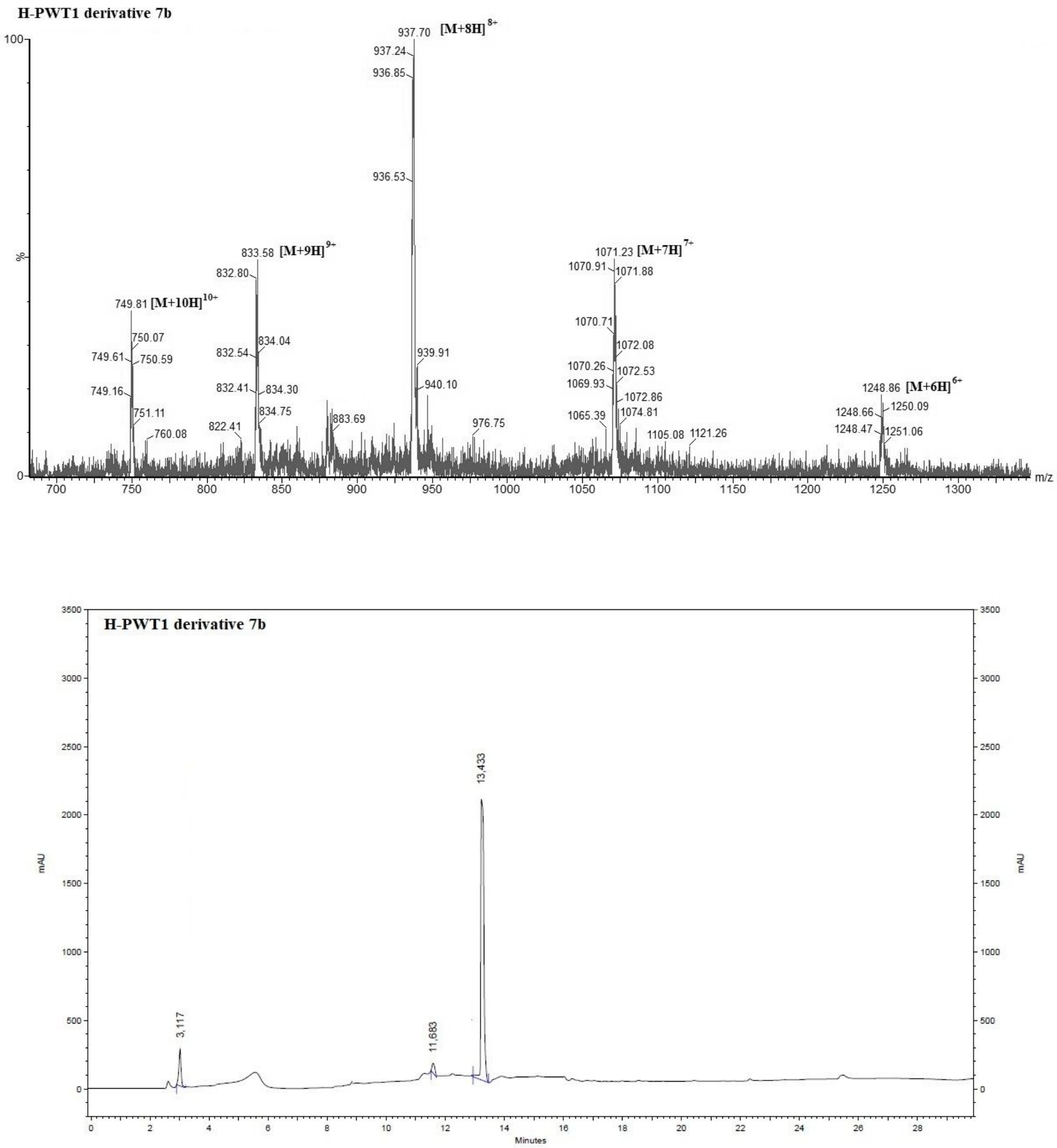


\section{H-PWT1 derivative 7c}
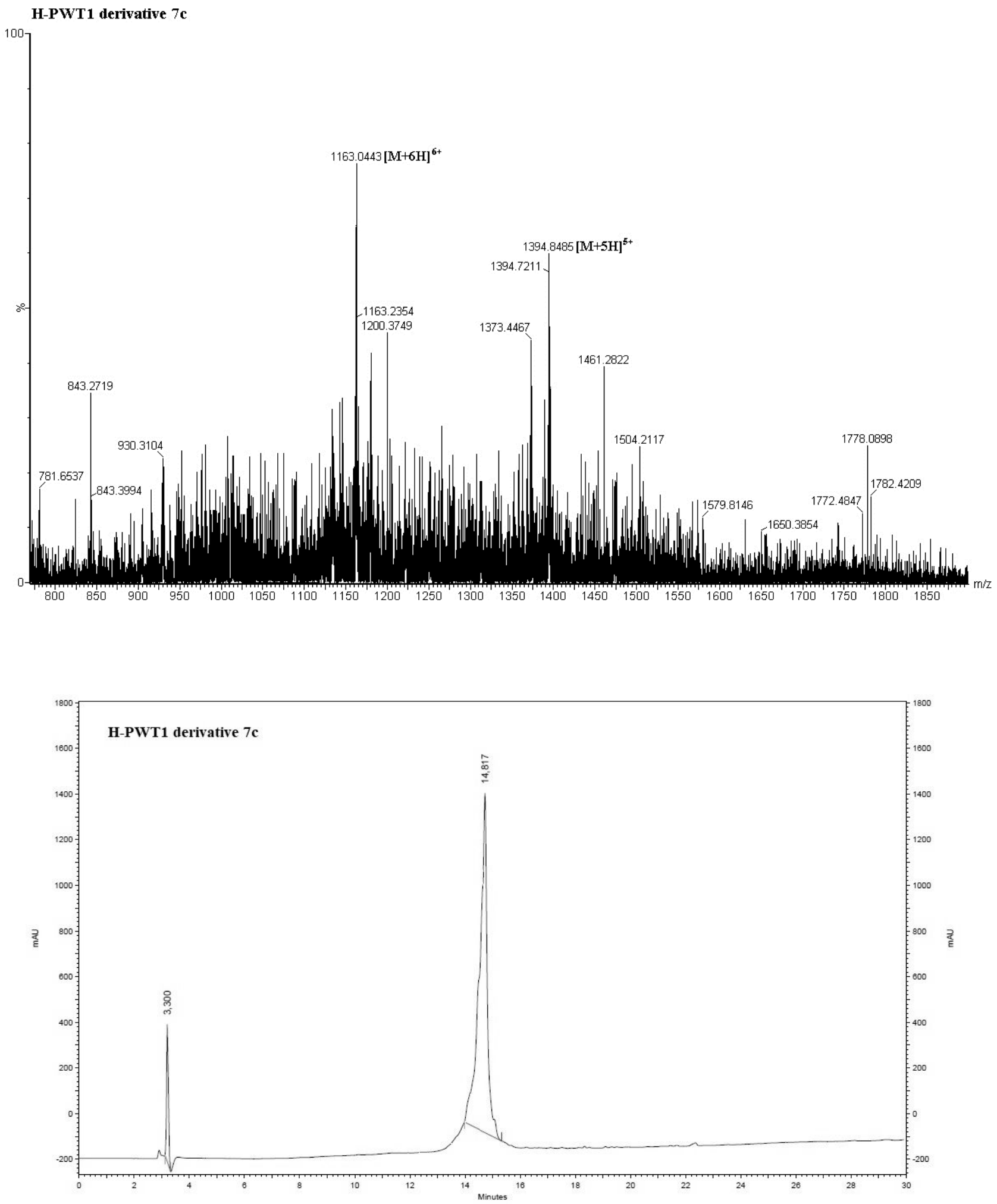
Homotetrameric derivative PWT1-N/OFQ
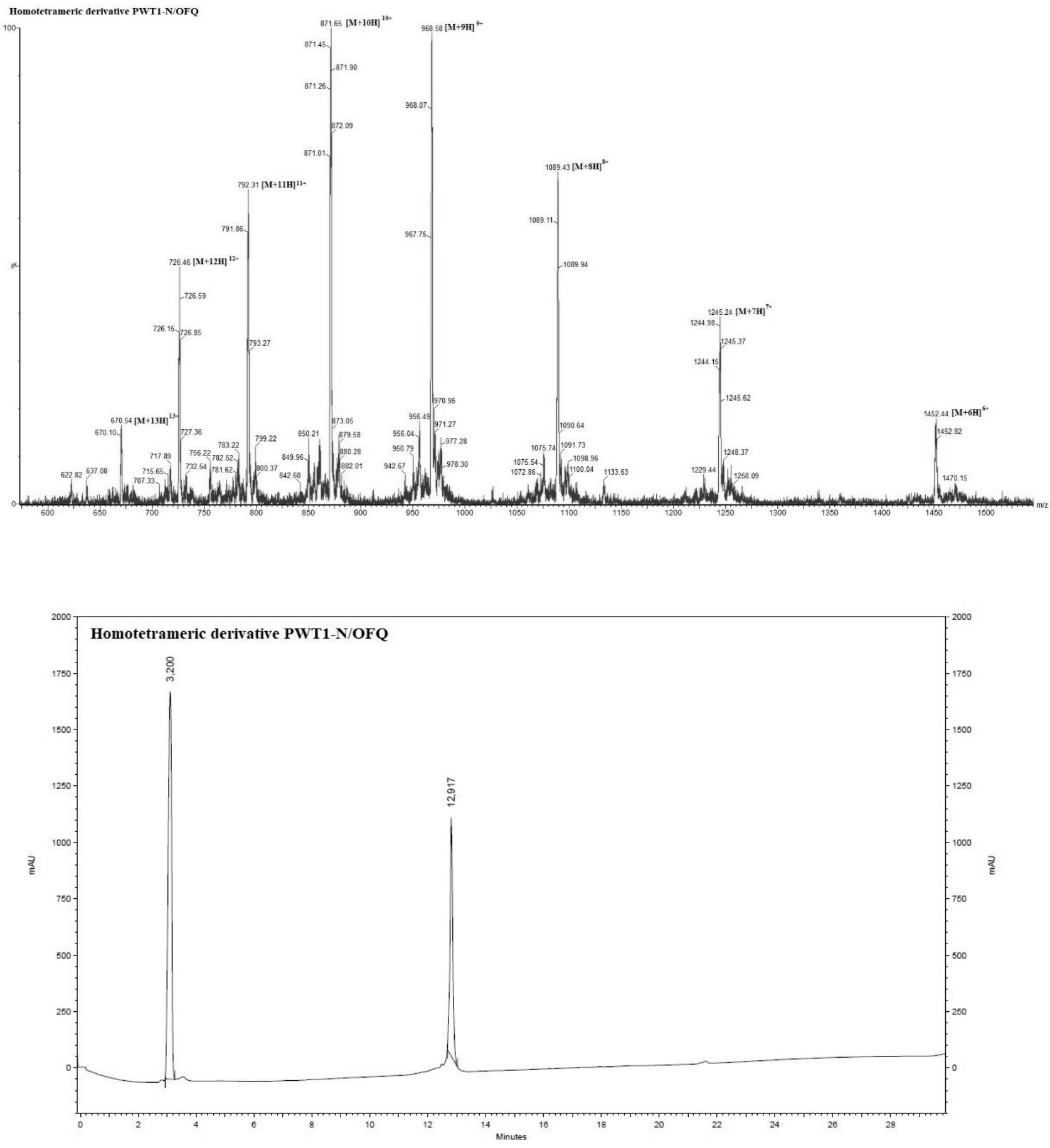


\section{Homotetrameric derivative PWT1-Dermorphin}
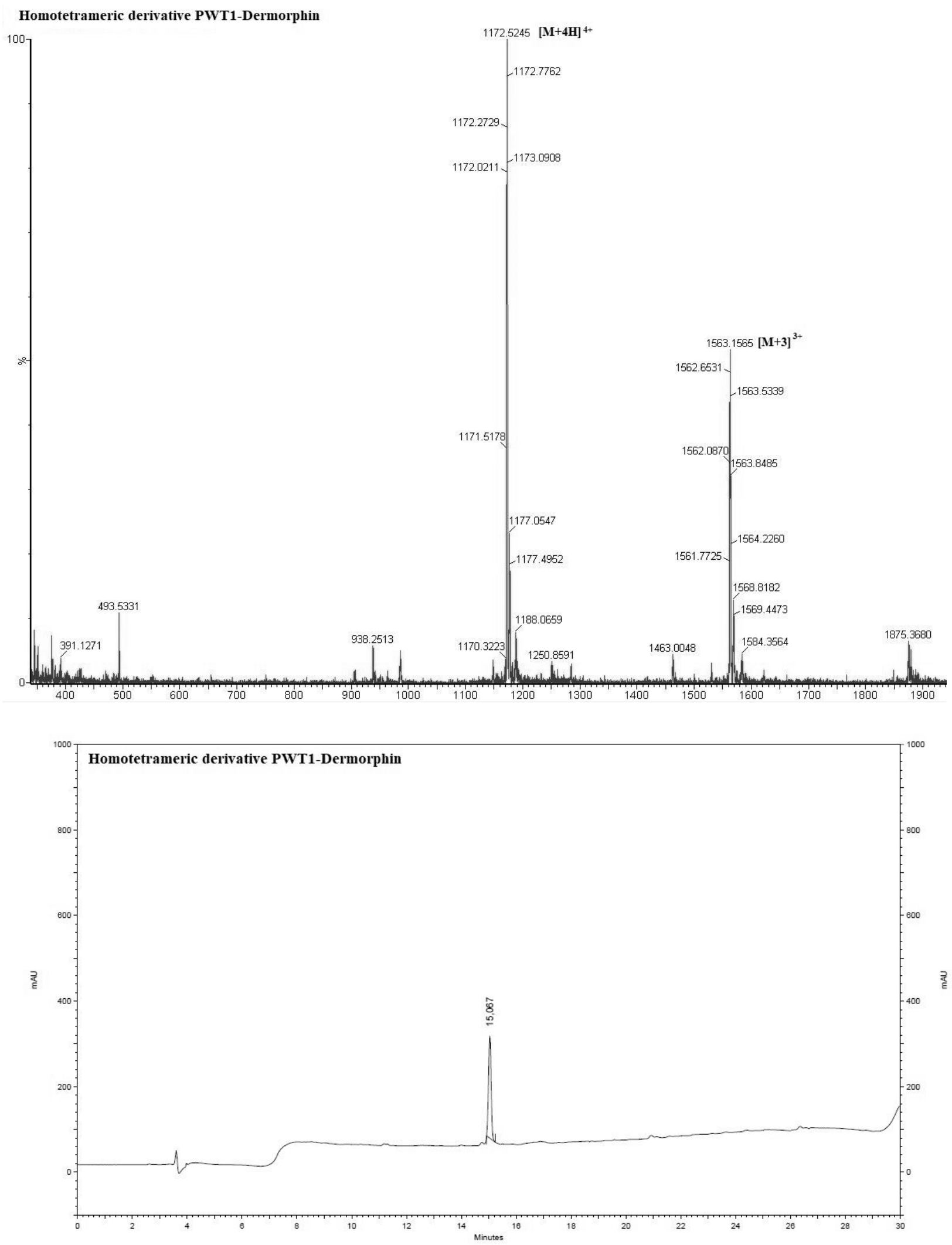
Homotetrameric derivative PWT1-dermorphin(O2Oc)
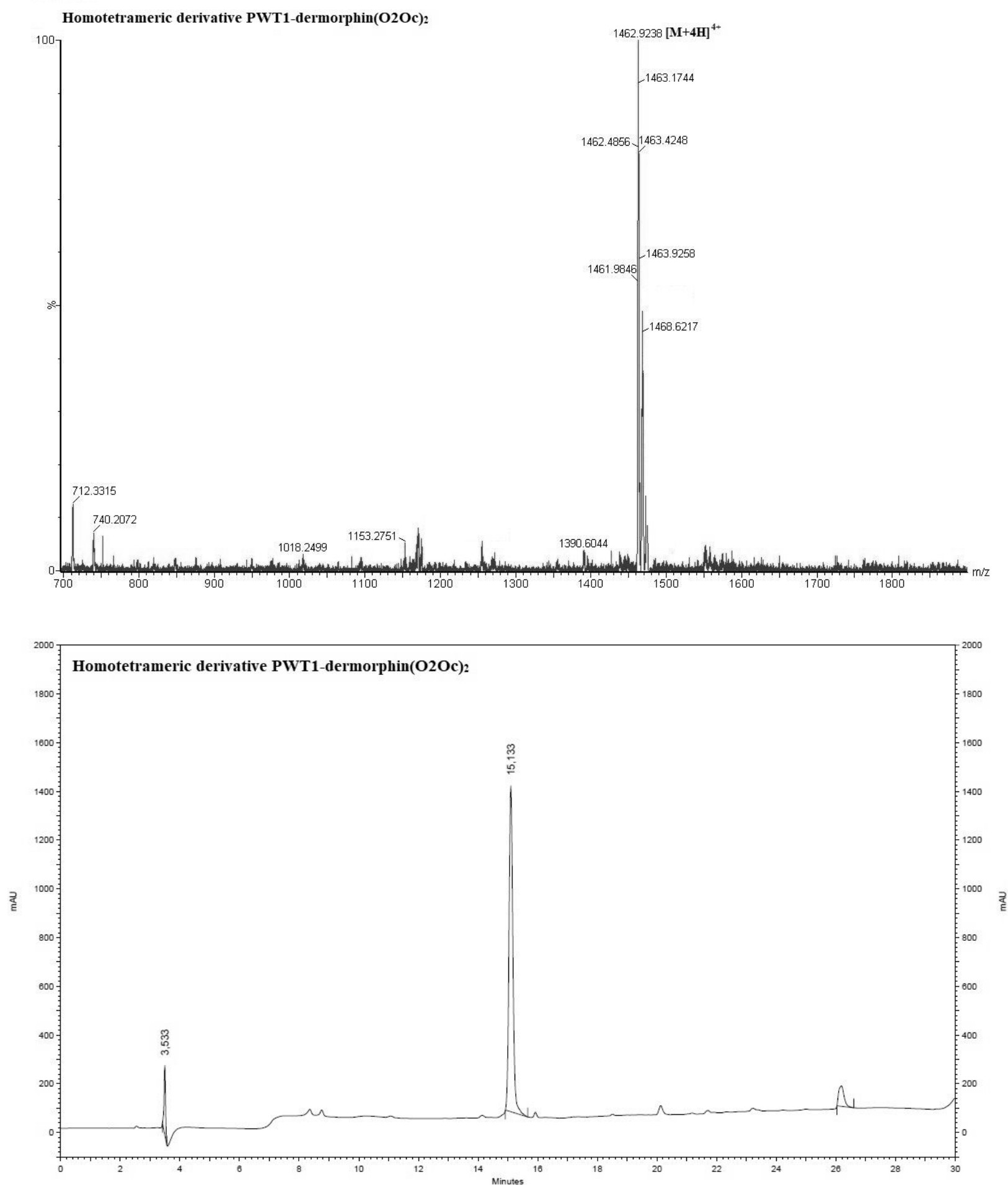


\section{Homotetrameric derivative PWT1-[Dmt $\left.{ }^{1}\right]$ dermorphin}

Homotetrameric derivative PWT1-[Dmt $\left.{ }^{\mathrm{l}}\right]$ dermorphin
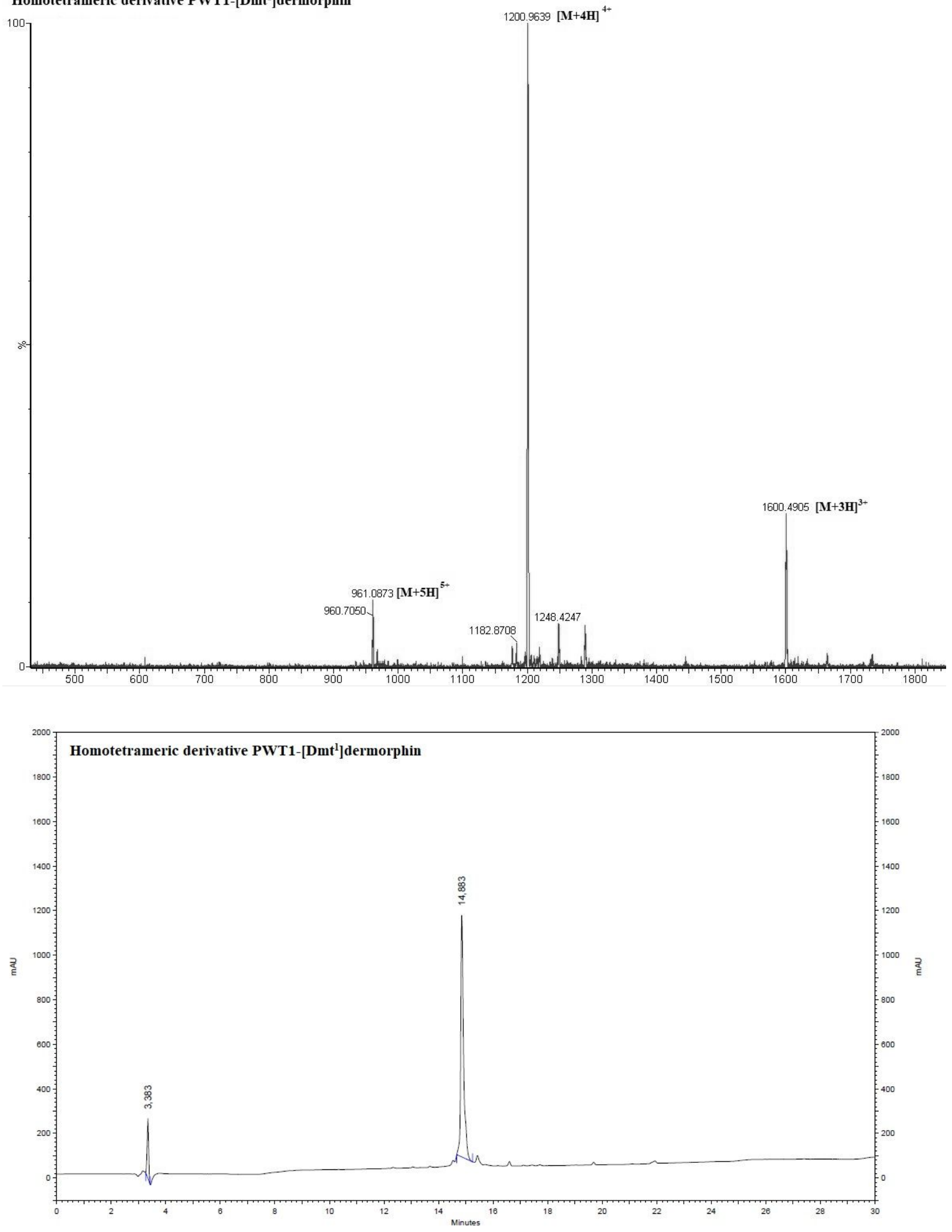